Journal of Financial Economics \& Investment

Vol. 2, No. 1, Januari 2022, pp. 1-12

\title{
PENGARUH VARIABEL MAKRO EKONOMI TERHADAP RETURN SAHAM PADA JAKARTA ISLAMIC INDEX (JII) PERIODE 2013 -2020
}

\author{
Yuszril Teguh Prasetyo ${ }^{a^{*}}$, Happy Febrina Hariyanib \\ Program Studi Ekonomi Pembangunan Fakultas Ekonomi dan Bisnis, Universitas Muhammadiyah \\ Malang,Jl. Raya Tlogomas 246, Malang-Jawa Timur, Indonesia \\ * Corresponding author: yuszrilteguh25@gmail.com
}

\begin{tabular}{|c|c|}
\hline Artikel Info & Abstract \\
\hline $\begin{array}{l}\text { Article history: } \\
\text { Received } 21 \text { Desember } 2021 \\
\text { Revised } 10 \text { Januari } 2022 \\
\text { Accepted } 20 \text { Januari } 2022 \\
\text { Available online } 28 \text { Januari } \\
2022\end{array}$ & $\begin{array}{l}\text { This study aims to determine the effect of } \\
\text { macroeconomic variables including BI-Rate, } \\
\text { exchange Rate, and Gross Domestic Product } \\
\text { Development on stock returns of the Jakarta Islamic } \\
\text { Index. The analytical method used in this study uses } \\
\text { panel data regression analysis. The coefficient of }\end{array}$ \\
\hline $\begin{array}{l}\text { Keywords: BI-rate; exchange } \\
\text { rate; gross domestic product; stock } \\
\text { return } \\
\text { JEL Classification: }\end{array}$ & $\begin{array}{l}\text { determination (R2) obtained an R-Squared value of } \\
0.233956 \text { or } 23.39 \% \text {. The result of this research is } \\
\text { that the BI-Rate has a significant negative effect on } \\
\text { JII's stock returns. The exchange Rate has a } \\
\text { significant negative effect on JII's stock returns. And } \\
\text { the development of Gross Domestic Product has a } \\
\text { significant positive effect on JII's stock returns. }\end{array}$ \\
\hline
\end{tabular}

\section{PENDAHULUAN}

Pasar modal adalah tempat dimana bertemunya penjual dan pembeli yang sedang melakukan transaksi pendanaan bagi perusahaan. Menurut Tandelilin (2010), adanya pasar modal ini juga menunjang perekonomian karena pasar modal dapat menghubungkan pihak yang membutuhkan dana dengan pihak mempunyai kelebihan dana. Selain itu, pasar modal dapat mendorong terciptanya alokasi dana yang efisien, karena dengan adanya pasar modal maka pihak yang kelebihan dana (investor) dapat memilih alterntif investasi yang memberikan tingkat pengembalian (return) yang paling optimal. Samsul (2015) mendefinisikan secara umum pasar modal adalah tempat atau sarana bertemunya permintaan dan penawaran atas instrument keuangan untuk jangka panjang umumnya lebih dari satu tahun.

Suyati (2015) meneliti tentang pengaruh indikator makroekonomi seperti inflasi, tingkat suku bunga dan nilai tukar Rupiah/Dolar AS. Teknik analisis data yang digunakan dalam penelitian ini adalah analisis regresi linier berganda. Hasil penelitian ini menunjukkan bahwa secara parsial bahwa inflasi memang berpengaruh signifikan terhadap return saham property, tingkat suku bunga berpengaruh signifikan terhadap return saham properti, dan nilai tukar Rupiah/Dolar AS berpengaruh signifikan terhadap return saham properti. Penelitian Hidayat et al., (2017) yang mengemukakan tentang pengaruh inflasi dan suku bunga dan nilai tukar rupiah serta jumlah uang beredar terhadap return saham. Dengan hasil uji $\mathrm{F}$ menunjukkan bahwa inflasi, suku bunga, nilai tukar rupiah dan jumlah uang beredar mempunya pengaruh yang signifikan terhadap returm saham indeks LQ 45 yang terdaftar pada Bursa Efek Indonesia. Hasil uji T menunjukkan bahwa 
variabel tingkat inflasi mempunyai pengaruh negatif signifikan terhadap return saham dan suku bunga mempunyai pengaruh positif signifikan terhadap return saham sedangkan nilai tukar rupiah dan jumlah uang beredar mempunyai pengaruh yang tidak signifikan terhadap return saham indeks LQ 45 yang terdaftar pada Bursa Efek Indonesia. Hasil penelitian oleh Bobbi \& Haryanto (2017) tentang pengaruh Foreigni Inflow, Inflasi, Suku Bunga, dan Kurs pada return saham. Dengan hasil Hasil penelitian menunjukkan bahwa Foreign Inflow berpengaruh positif signifikan terhadap return saham, sedangkan Inflasi, tingkat suku bunga dan nilai tukar tidak berpengaruh signifikan terhadap return saham. Berdasarkan hasil uji koefisien determinasi R2, variabel bebas dalam penelitian ini berpengaruh sebesar 31.7\% terhadap return saham Dewi et al (2019) dengan penelitianya tentang pengaruh TATO, NPM, DAR, Beta Saham, Inflasi dan PDB terhadap return saham pada Perusahaan Sub Sektor Kontruksi Bangunan yang Terdaftar Di Bursa Efek Indonesia Periode 2014 - 2017. Dan penelitian oleh Abdul Jabar \& Cahyadi (2020) tentang pengaruh variabel nilai tukar, inflasi, risiko sistematik, dan BI Rate terhadap return saham syariah di Jakarta Islamic Index (JII) periode 2015-2018. Dari penelitian dapat diambil kesimpulan bahwa secara simultan atau uji $\mathrm{F}$ terdapat pengaruh yang signifikan antara variabel bebas (X) yaitu variabel exchange Rate, inflasi, risiko sistematis dan BI Rate terhadap variabel terikat (Y) dengan nilai koefisien determinasi (Adjusted R Square) sebesar 0.148 atau sama dengan 14.8\%. Dan dengan uji parsial nilai tukar dan inflasi berpengaruh negatif, begitupun Bi-Rate dan resiko sistematis berpengaruh negatif.

Menurut Tandelilin (2010) Instrumen pasar modal dalam konteks praktis lebih banyak dikenal dengan sebutan sekuritas. Dan sekuritas yang di perdagangkan dipasar yang bersifat ekuitas Indonesia adalah saham baik saham biasa maupun saham preferen serta bukti right dan waran. Dari keempat sekuritas ekuitas ini, saham biasa merupakan sekuritas yang terpenting dan paling dikenal oleh masyarakat Indonesia. Oleh karenanya, sebutan pasar ekuitas sering dimengerti sebagai pasar saham

Investasi di Indonesia saat ini sedang mengalami perkembangan yang cukup baik. Hal ini ditandai dengan membaiknya indeks yang berkaitan dengan Indonesia yaitu Indeks Harga Saham Gabungan (IHSG), LQ45, Jakarta Islamic Index (JII), dan Indeks Saham Syariah Indonesia (ISSI). Perkembangan pasar modal ini diharapkan mampu untuk meningkatkan perekonomian Indonesia. Dimana pasar modal merupakan salah satu faktor penting dalam pembangunan ekonomi (Riantani \& Tambunan, 2013). Suciningtyas \& Khoiroh (2015) menyatakan bahwa Indonesia memiliki potensi besar dalam pengembangan produk investasi berbasis syariah. Perkembangan saham syariah dimulai pada Juli 2000 dengan adanya Jakarta Islamic Index. Perkembangan pasar modal syariah Indonesia didorong oleh lahirnya Indeks Saham Syariah Indonesia (ISSI) yang dikeluarkan oleh Bapepam-LK dan Syariah Nasional. Majelis Ulama Indonesia (DSN-MUI) 12 Mei 2011. Perkembangan saham syariah bisa dilihat pada gambar 1. 


\section{Gambar 1. Jumlah Saham Syariah Tahun 2013 - 2019}

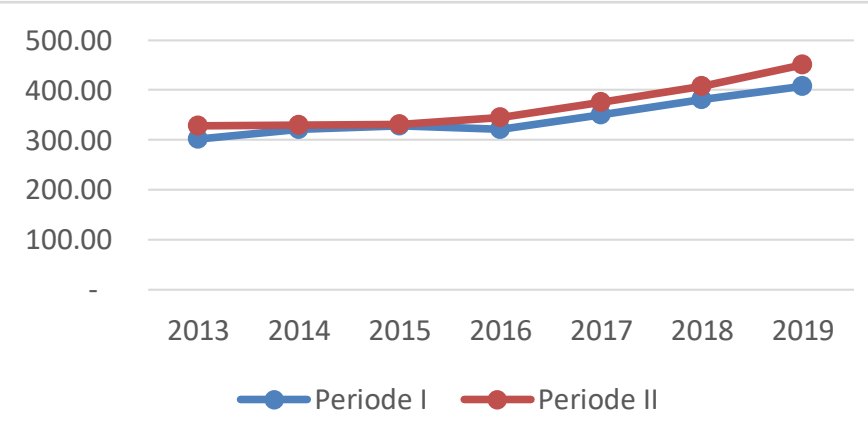

Sumber: Jumlah Saham Syariah Daftar Efek Syariah, 2020

Menurut Huda (2007) perkembangan instrumen syariah di pasar modal sudah terjadi sejak tahun 1997. Diawali dengan lahirnya reksadana syariah yang diprakarsai dana reksa selanjutnya, PT Bursa Efek Jakarta (BEJ) bersama dengan PT Dana Reksa Invesment Management (DIM) meluncurkan Jakarta Islamic Index (JII) yang mencakup 30 jenis saham dari emiten yang kegiatan usahanya memenuhi ketentuan tentang hukum syariah. Penentuan kriteria dari komponen JII tersebut disusun berdasarkan persetujuan dari Dewan Pengawas Syariah DIM. Samsul (2006) mendefinisikan saham sebagai tanda bukti kepemilikan perusahaan. Pemilik saham disebut juga pemegang saham (shareholder atau stockholder). Jadi dapat disimpulkan saham adalah surat bukti kepemilikan atau surat berharga yang bisa dijualbelikan.

Perkembangan saham syariah juga menunjukan hal yang positif pada jumlah saham per januari 2013 sampai 2019 yang terdapat pada Daftar Efek Syariah (DES) yang ditahun 2013 jumlah saham syariah 302 dan 328 meningkat sampai tahun 2019 dengan jumlah saham syariah 408 dan 451.

Samsul (2015) mendefinisikan return saham sebagai pendapatan yang dinyatakan dalam presentase dari modal awal investasi. Dapat disimpulkan bahwa return saham adalah pendapatan yang di peroleh investor dalam melakukan investasi di pasar saham, return terdapat 2 jenis yaitu: return ekpektasi atau return harapan adalah nilai return rata - rata. Jika kita memiliki distribusi probabilitas return suatu sekuritas, nilai return harapanya dapat dihitung dengan cara menentukan nilai rata - rata tertimbang dari distribusi return tersebut (Tandelilin, 2010), dan return realisasi adalah imbal hasil yang sudah terjadi. Perhitungan return realisasi berdasar pada data harga saham dimasa lalu (Jogiyanto, 2008).

Menurut Arif Afendi (2017) Terdapat banyak faktor yang mempengaruhi harga saham dan return saham, baik yang bersifat makro maupun mikro ekonomi. Faktor makro ada yang bersifat ekonomi maupun nonekonomi. Faktor makroekonomi terinci dalam beberapa variabel ekonomi, misalnya inflasi, suku bunga, kurs valuta asing, tingkat pertumbuhan ekonomi, Produk Domestik Bruto, harga bahan bakar minyak di pasar internasional, dan indeks saham regional. Menurut Tandelilin (2010) Kemampuan dalam memahami dan meramalkan kondisi ekonomi makro di masa datang akan sangat berguna untuk investor dalam mengambil 
keputusan investasi yang menguntungkan sehingga investor harus memperhatikan beberapa indikator ekonomi makro yang bisa membantu mereka dalam memahami dan meramalkan membuat keputusan dalam investasi. Berikut ini ada beberapa variabel ekonomi makro yang perlu diperhatikan investor dalam keputusan investasinya.

Menurut Afiyati \& Topowijono (2016) BI Rate merupakan faktor yang dapat mempengaruhi return saham karena jika suku bunga kredit naik, maka biaya modal yang dikeluarkan emiten akan semakin besar sehingga minat emiten untuk meminjam dana pada bank akan menurun karena beban bunga tersebut. Hal tersebut membuat dana pinjaman yang diperoleh emiten semakin kecil sehingga dapat menurunkan tingkat penjualan. Jika tingkat penjualan menurun, maka laba dalam perusahaan juga mengalami penurunan. Apabila laba turun maka harga saham juga akan mengalami penurunan diikuti oleh penurunan return yang diperoleh pemegang saham.

\section{Gambar 2. Tingkat BI- Rate Tahun 2013 - 2020}

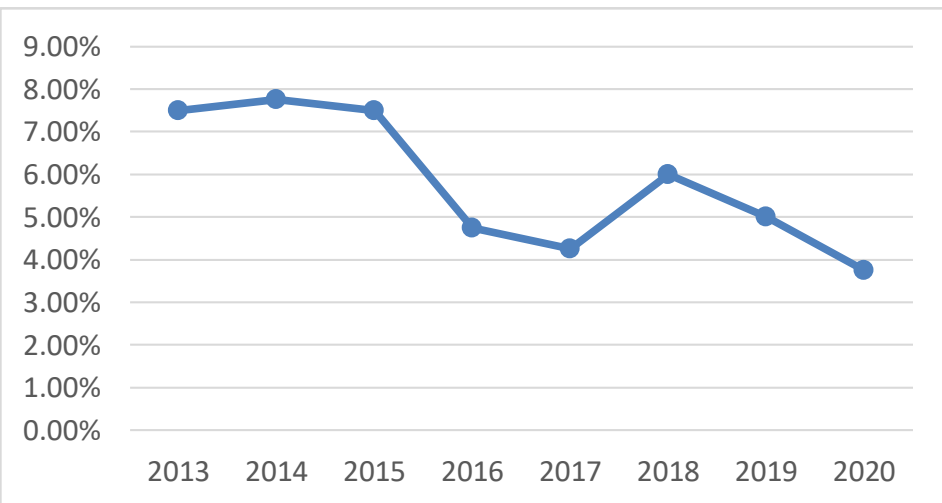

Sumber: Laporan BI-Rate Badan Pusat Statistik (BPS), 2020

Pada gambar 2 dapat diketahui bahwa BI-Rate mengalami fluktuasi dari tahun 2013 sampai 2020. Menurut Tandelilin (2010) tingkat suku bunga yang terlalu tinggi akan mempengaruhi nilai sekarang (present value) aliran kas perusahaan sehingga kesempatan - kesempatan investasi yang ada tidak akan menarik lagi. Selain itu tingkat bunga yang tinggi juga akan meningkatkan biaya modal yang harus ditanggung perusahaan. Dan juga peningkatan suku bunga menyebabkan pemodal atau investor menarik investasinya pada suatu saham dan memindahkanya pada investasi berupa tabungan maupun deposito. Selain itu, kenaikan tingkat suku bunga yang tinggi juga akan memicu para pemegang saham untuk beralih investasi ke deposito karena dianggap lebih menguntungkan. Dari penjelasan tersebut, dapat disimpulkan bahwa kenaikan tingkat suku bunga berpengaruh negatif terhadap return saham (Aditya, 2015).

Nilai tukar atau kurs merupakan pertukaran mata uang yang berbeda di berbagai negara. Perubahan nilai tukar sangat penting dalam pertumbuhan ekonomi karena dapat mempengaruhi harga produk maupun jasa dalam negeri dan luar negeri. (Afiyati \& Topowijono, 2016). Menurut Sukirno 
(2011) kurs valuta asing menunjukkan harga atau nilai mata uang suatu negara dinyatakan dalam nilai mata uang negara lain.

Tabel 1. Perkembangan Nilai Tukar Rupiah terhadap US Dollar Tahun $2013-2020$

\begin{tabular}{rcc}
\hline \multirow{2}{*}{ TAHUN } & \multicolumn{2}{c}{ TINGKAT PERKEMBANGAN NILAI TUKAR } \\
\cline { 2 - 3 } & $(\mathrm{Rp})$ & $(\%)$ \\
\hline 2013 & $12,189.00$ & \\
2014 & $12,440.00$ & $2.06 \%$ \\
2015 & $13,795.00$ & $10.89 \%$ \\
2016 & $13,436.00$ & $-2.60 \%$ \\
2017 & $13,548.00$ & $0.83 \%$ \\
2018 & $14,481.00$ & $6.89 \%$ \\
2019 & $13,901.00$ & $-4.01 \%$ \\
2020 & $14,105.00$ & $1.47 \%$ \\
\hline
\end{tabular}

Sumber: Kementerian perdagangan, 2020

Pada tabel 1 dapat diketahui bahwa nilai tukar rupiah terhadap US Dollar mengalami fluktuasi setiap tahunya. Tahun 2013 nilai tukar sebesar Rp. 12.189,00. Di tahun 2014 - 2015 mengalami depresiasi sebesar 2,06\% dan 10,89\% . Ditahun 2016 nilai tuukar mengalami apresiasi sebesar 2,60\%. Nilai tukar rupiah mengalami depresiasi kembali di tahun 2017- 2018 sebesar 0,83\% dan 6,89\%. Nilai tukar rupiah mengalami apresiasi di tahun 2019 sebesar 4,01\% dan terdepresiasi kembali pada tahun 2020 sebesar 1,47\%.. Tandelilin (2010) menyatakan bahwa nilai tukar merupakan sinyal positif, jika nilai tukar terapresiasi maka harga saham akan meningkat, begitu juga sebaliknya. Jika nilai tukar terdepresiasi maka harga saham akan menurun. Karena menguatnya kurs rupiah terhadap mata uang asing akan menurunkan biaya impor bahan baku untuk produksi, dan akan menurunkan tingkat suku bunga yang berlaku.

Tabel 2. Perkembangan Produk Domestik Bruto Harga Konstan Indonesia tahun 2013 - 2020

\begin{tabular}{clc}
\hline \multirow{2}{*}{ TAHUN } & \multicolumn{2}{c}{ Perkembangan Produk Domestik Bruto } \\
\cline { 2 - 3 } 2013 & Rp. 8,156,497.80 Miliar & \\
2014 & Rp. 8,564,866.60 \\
2015 & Rp. 8,982,517.10 & $5.01 \%$ \\
2016 & Rp. 9,434,613.40 & $4.88 \%$ \\
2017 & Rp. 9,912,928.10 & $5.03 \%$ \\
2018 & Rp. 10,425,851.90 & $5.07 \%$ \\
2019 & Rp. 10,949,037.80 & $5.17 \%$ \\
2020 & Rp. 10,722,442.70 & $5.02 \%$ \\
\hline
\end{tabular}

Sumber KEMENDAG, 2020

Pada tabel 2 dapat diketahui bahwa perkembangan Produk Domestik Bruto di Indonesia mengalami kenaikan setiap tahunya dari tahun 2013 2019 dan mengalami penurunan di tahun 2020. Produk Domestik Bruto meningkat dari tahu 2013 - 2016 sebesar 5,01\%, 4,88\%, dan 5,03\%. Produk Domestik Bruto meningkat kembali di tahun 2017 - 2019 sebesar 5,07\%, 
5,17\% dan 5,02\%. Ditahun 2020 Produk Domestik Bruto mengalami penurunan sebesar $-2,07 \%$. Menurut Sukirno (2011) data produk nasional dapat pula digunakan untuk: Menilai prestasi pertumbuhan ekonomi, menentukan tingkat kemakmuran masyarakat dan perkembanganya. Untuk menilai prestasi pertumbuhan ekonomi harus terlebih dahulu dihitung pendapatan nasioanl rill yaitu PNB atau PDB yang dihitung menurut harga harga yang berlaku dalam tahun dasar. Tingkat (persentasi pertambahan) pertumbuhan ekonomi dihitung dari pertambahan Produk Domestik Bruto rill dari tahun ke tahun. Menurut Tandelilin (2010) Produk Domestik Bruto adalah ukuran produksi barang dan jasa total suatu negara. Pertumbuhan Produk Domestik Bruto yang cepat merupakan indikasi terjadinya pertumbuhan ekonomi. Jika pertumbuhan ekonomi membaik, maka daya beli masyarkat pun akan meningkat, sehingga dapat meningkatkan permintaan terhadap produk perusahaan. Dan ini merupakan kesempatan bagi perusahaan-perusahaan untuk meningkatkan penjualanya. Sehingga disimpulkan bahwa ketika meningkatnya Produk Domestik Bruto merupakan sinyal positif untuk investasi.

Berdasarkan penelitian terdahulu dan penjelasan diatas tujuan Penelitian ini ingin meneliti pengaruh variabel makroekonomi terhadap return saham jii denngan relevansi pada penelitian ini dengan penelitian terdahulu ialah memiliki perbedaan pada pembaruan periode yang diteliti karena peneliti terdahulu menggunakan rentan waktu di bawah tahun 2020, selain itu perbedaan variabel pada PDB dimana penelitian ini menggunakan data perkembangan PDB tahun 2013 - 2020.

\section{METODE PENELITIAN}

Objek penelitian ini adalah return saham perusahaan di Jakarta Islamic Index periode 2013 - 2020. Populasi penelitian yaitu 30 perusahaan dengan sampel sebanyak 10 perusahaan. Jenis data dalam penelitian ini menggunkan data Sekunder yang bersumber pada data publikasi Bursa Efek Indonesia (BEI), Badan Pusat Statistik (BPS), Kementrian Perdagangan (Kemendag), dan data historical price Yahoo Finance.com, serta berbagai berbagai literatur buku dan jurnal yang memuat topik mengenai penelitian yang diteliti.

Penelitian ini menggunakan analisis regresi data panel. Analisis regresi data panel adalah suatu metode yang menjelaskan mengenai gabungan dari data antar waktu (time-series) dengan data antar individu (cross-section). Adapun persamaan regresinya adalah sebagai berikut:

$$
Y \_i t=\alpha \_i+\beta \_1 X \_1 i t+\beta \_2 X \_2 i t+\beta \_3 X \_3 i t+\varepsilon \_i t
$$

Keterangan:

$\begin{array}{ll}\text { Y_it } & =\text { Return Saham } \\ \alpha \_\mathrm{i} & =\text { konstanta } \\ \beta \_1-\beta \_3 & =\text { koefisien variabel independen } 1-3 \\ \text { X_1 } & =\text { BI- Rate } \\ \text { X_2 } & =\text { Nilai Tukar } \\ \text { X_3 } & =\text { Perkembangan Produk Domestik Bruto } \\ \varepsilon_{-} \text {it } & =\text { nilai gangguan atau error }\end{array}$


Untuk mengetahui pengaruh antar variabel bebas dan terikat maka dilakukan uji hipotesis yang terdiri dari Uji F, Uji t dan Koefisien Determinasi atau (R2). Secara umum ada tiga model untuk menntukan model terbaik dalam menggunakan model regresi data panel yaitu mulai dari Common Effect, Fixed Effect, dan Random Effect. Penentuan model terbaik dalam ketiga model diatas maka dilakukan melalui tiga uji, yaitu uji Chow, uji Hausman, dan uji LM.

Uji Chow digunakan untuk menentukan model yang lebih sesuai antara model Common Effect (CE) dan model Fixed Effect (FE). Uji Hausman digunakan untuk menentukan model terbaik atau sesuai antara model Random Effect (RE) dan model Fixed Effect (FE). Uji LM digunakan untuk menentukan model yang lebih sesuai antara model Common Effect (CE) dan model Random Effect (RE).

\section{HASIL DAN PEMBAHASAN}

Dalam penelitian ini melakukan deskripsi terhadap variabel - variabel penelitian yang terdiri dari (X1) BI-Rate, (X2) Nilai Tukar, (X3) Perkembangan Produk Domestik Bruto dan (Y) Return Saham JII. Dapat dilihat hasil dari uji analisis statistik deskriptif berdasarkan variabel variabel yang telah disebutkan dijelaskan pada tabel berikut:

Tabel 3. Hasil Analisis Deskriptif

\begin{tabular}{|c|c|c|c|c|}
\hline & RETURN & LOG(BI_RATE) & LOG(KURS) & PDB \\
\hline Mean & 0.083748 & -2.879481 & 9.507913 & 0.042088 \\
\hline Median & 0.051433 & -2.904571 & 9.523028 & 0.050250 \\
\hline Maximum & 2.291262 & -2.557477 & 9.580593 & 0.055600 \\
\hline Minimum & -0.548966 & -3.283414 & 9.408289 & -0.020700 \\
\hline Std. Dev. & 0.354910 & 0.265721 & 0.056561 & 0.023957 \\
\hline kewness & 3.112646 & -0.080027 & -0.673150 & 2.238589 \\
\hline Kurto & 20.06374 & 1.501424 & 2.152037 & 6.072535 \\
\hline Jarq & 109 & 7.57 & 8.43 & 98.28534 \\
\hline \multirow[t]{2}{*}{ Probability } & 0.000000 & 0.022696 & 0.014709 & 0.000000 \\
\hline & RETURN & LOG(BI_RATE) & LOG(KURS) & PDB \\
\hline $\mathrm{um}$ & 6.699869 & -230.3585 & 760.6330 & 3.367000 \\
\hline Sum Sq. Dev. & 9.950943 & 5.578014 & 0.252731 & 0.045339 \\
\hline bse & 80 & 80 & 8 & 80 \\
\hline
\end{tabular}

Pada tabel 3 diperoleh jumlah pengukuran (n) sebanyak 80 observasi. Pada variabel Return Saham diperoleh Mean sebesar 0.083748 artinya umumnya Return Saham antara tahun 2013-2020 ada dikisaran nilai 0.083748 persen. Nilai Median sebesar 0.051433 artinya $50 \%$ dari jumlah pengamatan memiliki nilai kurang dari 0.051433 persen. Nilai Maximum dan Minimum sebesar 2.291262 dan -0.548966 artinya range observasi Return Saham ada diantara nilai -0.548966 sampai 2.291262 persen. 
Nilai standar deviasi sebesar 0.354910 artinya jarak/deviasi nilai observasi dari nilai rata-ratanya adalah sekitar 0.354910 persen. Nilai Sqewness positif menunjukkan bahwa distribusi data miring ke kanan (Skewed Right).

Pada varibel BI-Rate diperoleh Mean sebesar 2.879481 artinya umumnya BI-Rate antara tahun 2013 - 2020 ada dikisaran nilai 2.879481 persen. Nilai median sebesar 2.904571 artinya 50\% dari jumlah pengamatan memiliki nilai kurang dari 2.904571 persen. Nilai Maximum dan Minimum sebesar -2.557477 dan -3.283414 artinya range observasi BI - Rate ada di antara nilai -3.283414 sampai -2.557477 persen. Nilai standar deviasi sebesar 0.265721 artinya jarak/deviasi nilai observasi dari nilai rata-ratanya adalah sekitar 0.265721 persen. Nilai Sqewness negatif menunjukkan bahwa disrtibusi data miring ke kiri (Skewed left).

Pada varibel Nilai Tukar diperoleh Mean sebesar 9.507913 artinya umumnya Nilai Tukar antara tahun 2013 - 2020 ada dikisaran nilai 9.507913 persen. Nilai Median sebesar 9.523028 artinya 50\% dari jumlah pengamatan memiliki nilai kurang dari 9.523028 persen. Nilai Maximum dan Minimum sebesar 9.580593 dan 9.408289 artinya range observasi Nilai Tukar ada di antara nilai 9.408289 sampai 9.580593 persen. Nilai standar deviasi sebesar 0.056561 artinya jarak/deviasi nilai observasi dari nilai rataratanya adalah sekitar 0.056561 persen. Nilai Sqewness negatif menunjukkan bahwa disrtibusi data miring ke kiri (Skewed left).

Pada varibel perkembangan Produk Domestik Bruto diperoleh Mean sebesar 0.042088 artinya umumnya Perkembangan Produk Domestik Bruto antara tahun 2013 - 2020 ada dikisaran nilai 0.042088 persen. Nilai Median sebesar 0.050250 artinya $50 \%$ dari jumlah pengamatan memiliki nilai kurang dari 0.050250 persen. Nilai Maximum dan Minimum sebesar 0.055600 dan -0.020700 artinya range observasi Nilai Tukar ada di antara nilai -0.020700 sampai 0.055600 persen. Nilai standar deviasi sebesar 0.023957 artinya jarak/deviasi nilai observasi dari nilai rata-ratanya adalah sekitar 0.023957 persen. Nilai Sqewness positif menunjukkan bahwa disrtibusi data miring ke kanan (Skewed right).

Dalam menentukan model terbaik pada analisis regresi data panel menggunakan Uji Chow dan Uji Hausman. Uji Chow yaitu uji yang membandingkan model Common Effect (CE) dengan model Fixed Effect (FE) ,Uji Hausman Uji Hausman merupakan uji pembanding antara model Random Effect (RE) dengan model Fixed Effect (FE) dan yang terakhir uji LM untuk membandingkan model Common Effect (CE) dan Random Effect(RE).

Tabel 4. Hasil Uji Chow

\begin{tabular}{lrrr}
\hline Effects Test & Statistic & d.f. & Prob. \\
\hline Cross-section F & 1.431274 & $(9,64)$ & 0.1938 \\
Cross-section Chi-square & 14.120398 & 9 & 0.1181 \\
\hline
\end{tabular}


Hasil Uji chow menggunakan model Fixed Effect (FE), dapat dilihat bahwa nilai Prob Cross-Section F sebesar 0.1181 hal ini menunjukan bahwa nilai tersebut lebih besar dari $\alpha=0.05$ sehingga diputuskan untuk menerima H0. Dengan model Common Effect (CE) lebih sesuai.

Tabel 5. Hasil uji Hausman

\begin{tabular}{lrrr}
\hline Test Summary & $\begin{array}{r}\text { Chi-Sq. } \\
\text { Statistic }\end{array}$ & Chi-Sq. d.f. & Prob. \\
\hline Cross-section random & 6.600941 & 3 & 0.0858 \\
\hline
\end{tabular}

Dari Hasil Uji Hausman dapat dilihat bahwa nilai Prob Cross-Section Random sebesar 0.0858 hal ini menunjukkan bahwa nilai tersebut lebih besar dari $\alpha=0.05$ sehingga diputuskan untuk menerima H0, dengan kata lain model Random Effect (RE) lebih sesuai.

Tabel 6. Hasil Uji LM

\begin{tabular}{lccc}
\hline & \multicolumn{3}{c}{ Test Hypothesis } \\
& section & Time & Both \\
\hline Breusch-Pagan & $\begin{array}{l}0.270627 \\
(0.6029)\end{array}$ & $\begin{array}{l}2.896096 \\
(0.0888)\end{array}$ & $\begin{array}{l}3.166723 \\
(0.0752)\end{array}$ \\
\hline
\end{tabular}

Hasil Uji LM menggunakan model Common Effect (CE), dapat diketahui bahwa nilai Prob Cross-Section Breusch-Pagan sebesar 0.6029 hal ini menunjukkan bahwa nilai tersebut lebih besar dari $\alpha=0.05$ sehingga diputuskan untuk menerima H0, dengan kata lain model Common Effect (CE) lebih sesuai.

Berdasarkan hasil pengujian estimasi model data panel dengan menggunakan uji Chow, uji Hausman dan Uji LM maka dapat diambil kesimpulan bahwasanya model data panel yang tepat dalam melakukan uji hopitesis adalah Model Commond Effect.

Tabel 7. Hasil Regresi Model CE

\begin{tabular}{crlrc}
\hline Variable & Coefficient & Std. Error & t-Statistic & Prob. \\
\hline C & 18.14977 & 4.612112 & 3.935240 & 0.0002 \\
LOG(BI_RATE) & -0.455804 & 0.126651 & -3.598891 & 0.0006 \\
LOG(KURS) & -2.054889 & 0.502133 & -4.092324 & 0.0001 \\
PDB & 2.713512 & 1.217163 & 2.229374 & 0.0289 \\
& Effect specification & & \\
F-statistic & 7.431603 & R-squared & 0.233956 \\
Prob(F-statistic) & 0.000207 & Adjusted R-squared & 0.202475 \\
\hline
\end{tabular}

Pada tabel 7 nilai Prob F sebesar $0.000207<0.05$ maka dapat disimpulkan bahwa terdapat pengaruh minimal satu diantara variabel BIRate, Nilai Tukar, dan Perkembangan Produk Domestik Bruto (PDB) terhadap return saham Jakarta Islamic Index (JII). Nilai T-statistic BI-Rate sebesar -3.598891 > T-tabel (1.19967). Sedangkan nilai prob 0.0006 atau $<\alpha$ $=0.05$, Sehingga dapat dinyatakan menerima H1 dan menolak H0. Maka, dapat dinyatakan bahwa variabel BI-Rate berpengaruh negatif signifikan 
terhadap return saham Jakarta Islamic Index (JII). Nilai T-statistic Nilai Tukar sebesar -4.092324 > T-tabel (1.19967). Sedangkan nilai prob 0.0001 atau $<\alpha$ $=0.05$, Sehingga dapat dinyatakan menerima H1 dan menolak H0. Maka, dapat dinyatakan bahwa variabel Nilai Tukar berpengaruh negatif signifikan terhadap return saham Jakarta Islamic Index (JII). Nilai T-statistic Perkembangan PDB sebesar $2.229374>$ T-tabel (1.19967). Sedangkan nilai prob 0.0289 atau $<\alpha=0.05$, Sehingga dapat dinyatakan menerima H1 dan menolak H0. Maka, dapat dinyatakan bahwa variabel Perkembangan PDB berpengaruh Positif signifikan terhadap return saham Jakarta Islamic Index (JII).

Koefisien determinasi (R2) diperoleh nilai R-Squared sebesar 0.233956 atau 23.39\% Artinya, keragaman variabel return saham dapat dijelaskan oleh variabel BI-Rate, Nilai Tukar, dan Perkembagan Produk Domestik Bruto sebesar $23.39 \%$, sedangkan sisanya sebesar $76.61 \%$ dijelaskan oleh variabel lain di luar model yang diteliti.

Variabel BI-Rate negatif signifikan terhadap return saham. Dengan kata lain ketika BI- Rate meningkat maka return saham akan menurun. Hal ini terjadi karena Suku bunga yang tinggi mengurangi nilai sekarang dari arus kas perusahaan mendatang, sehingga daya tarik dalam investasi di pasar modal menjadi turun. Selain itu tingkat bunga yang tinggi juga akan meningkatkan biaya modal yang harus ditanggung perusahaan yang berpengaruh juga terhadap harga saham perusahaan. Hasil Penelitian ini sejalan dengan penelitian penelitian yang dilakukan Aditya (2015) yang meneliti return saham perusahaan yang tercatat di Jakarta Islamic Index (JII) periode 2011 - 2015 dan penelitian yang dilakukan Abdul Jabar \& Cahyadi (2020) yang meneliti return saham syariah di Jakarta Islamic Index (JII) periode 2015 - 2018.

Nilai Tukar memiliki pengaruh negatif signifikan yang artinya ketika nilai tukar mengalami depresiasi, maka akan menurunkan return saham. Hal ini terjadi karena ketika kurs rupiah mengalami depresiasi akan menimbulkan sinyal negatif bagi perekonomian Indonesia, dimana ketika kurs rupiah melemah akan meningkatkan biaya produksi terutama biaya impor bahan baku dan juga diikuti mingkatnya tingkat bunga yang berlaku, hal ini akan memberikan dampak positif pada laba perusahaan yang pada akhirnya akan menaikan pendapatan per lembar saham., hasil penelitian ini sesusai dengan dilakukan, Suyati (2015) yang meneliti return saham properti dan penelitian yang dilakukan Abdul Jabar \& Cahyadi (2020) yang meneliti return saham syariah di Jakarta Islamic Index (JII) periode 2015 - 2018. Dengan hasil penelitian yang menyatakan bahwa Nilai Tukar berpengaruh negatif terhadap return saham.

Variabel perkembangan Produk Domestik Bruto berpengaruh positif signifikan. Dengan kata lain ketika perkembangan Produk Domestik Bruto meningkat makan akan meningkatkan return saham. Meningkatnya Produk Domestik Bruto suatu negara menandakan meningkatnya kesejahteraan masyarakat pada suatu negara. Meningkatnya kesejahteraan masyarakat maka akan mempengaruhi pola konsumsi masyarakat. Peningkatan pola 
konsumsi masyarakat dapat meningkatkan konsumsi masyarakat terhadap produk barang dan jasa sehingga akan meningkatkan perkembangan investasi. Penelitian ini dengan sejalan dengan penelitian Aditya (2015) yang meneliti return saham perusahaan yang tercatat di Jakarta Islamic Index (JII) periode $2011-2015$.

\section{KESIMPULAN}

Berdasarkan hasil analisis dan pembahasan mengani pengaruh variabel makro terhadap return saham di Jakarta Islamic Index (JII), dapat disimpulkan bahwa: BI-Rate berpengaruh negatif signifikan terhadap return saham di Jakarta Islamic Index (JII). Hasil menunjukan bahwa ketika terjadi kenaikan BI-Rate akan menurunkan return saham di Jakarta Islamic Index (JII). Nilai Tukar berpengaruh negatif signifikan terhadap return saham di Jakarta Islamic Index (JII). Hasil ini menunjukan bahwa ketika terjadi kenaikan pada Nilai Tukar akan menurunkan return saham di Jakarta Islamic Index (JII). Perkembangan Produk Domestik Bruto (PDB) berpengaruh positif signifikan terhadap return saham di Jakarta Islamic Index (JII). Hasil ini menunjukan bahwa ketika Perkembangan Produk Domestik Bruto mengalami kenaikan maka akan meningkatkan return saham Jakarta Islamic Index (JII).

\section{DAFTAR PUSTAKA}

Abdul Jabar, A. K., \& Cahyadi, I. F. (2020). Pengaruh Exchange Rate, Inflasi, Risiko Sistematis Dan BI Rate Terhadap Return Saham Syariah Di Jakarta Islamic Index (JII ) Periode 2015-2018. 4(1), 12-39.

Aditya, A. Y. (2015). Pengaruh Variabel Makro Ekonomi Terhadap Return Saham Perusahaan Yang Tercatat Di Jakarta Islamic Index ( JII ). 118142.

Afiyati, H. T., \& Topowijono. (2 C.E.). PENGARUH INFLASI , BI RATE DAN NILAI TUKAR TERHADAP RETURN SAHAM (Studi Pada Perusahaan Subsektor Food \& Beverages Yang Terdaftar Di Bursa Efek Indonesia Periode 20132016). 61(2).

Arif Afendi. (2017). PENGARUH VARIABEL MAKRO EKONOMI TERHADAP INDEKS SAHAM DI JAKARTA ISLAMIC INDEX (JII) (Periode 2012-2016). SEGMEN Jurnal Manajemen Dan Bisnis, 13(2), 48-72.

Bobbi, \& Haryanto, A. M. (2017). ANALISIS PENGARUH FOREIGN INFLOW, INFLASI, SUKU BUNGA DAN KURS PADA RETURN SAHAM (Studi kasus pada sektor keuangan periode Juli 2016 - Januari 2017). 6, 1-11.

Dewi, Febrianti, I., Soepardi, Mulyadi, E., \& Mulya, Y. (2019). Pengaruh Total Asset Turn Over (Tato), Net Profit Margin (Npm), Debt To Asset Ratio, (Dar), Beta Saham, Inflasi Dan Produk Domestik Bruto Terhadap Return Saham Pada Sub Sektor Kontruksi Bangunan Yang Terdaftar Di Bursa Efek Indonesia Periode 2014 - 2017. Jurnal Online Mahasiswa (JOM) Bidang Manajemen, 4(4), 1-20.

Hidayat, L. R., Setyadi, D., Azis, M., Bunga, S., Inflasi, T., \& Bunga, T. S. (2017). Influence of inflation and interest Rate and rupiah exchange Rate and 
money supply to stock return. 19(2), 148-154.

Huda, N., \& Edwin Nasution, M. (2007). Investasi pada Pasar Modal Syariah. Jogiyanto. (2008). Teori Portofolio dan analisis Investasi. BPFE.

Riantani, S., \& Tambunan, M. (2013). Analisis Pengaruh Variabel Makroekonomi dan Indeks Global terhadap Return Saham. Seminar Nasional Teknologi Informasi \& Komunikasi, 2013(16), 532-537.

Samsul, M. (2006). Pasar Modal dan Manajemen Portofolio. Erlangga.

Samsul, M. (2015). Pasar Modal dan Manajemen Portofolio (ke 2). Erlangga.

Suciningtyas, S. A., \& Khoiroh, R. (2015). ANALISIS DAMPAK VARIABEL MAKRO EKONOMI TERHADAP INDEKS SAHAM SYARIAH INDONESIA. 398-412.

Sukirno, S. (2011). Makroekonomi Teori Pengantar (ketiga). PT. Raja Grafindo Persada.

Suyati, S. (2015). Pengaruh Tingkat Inflasi, Suku Bunga Dan Nilai Tukar Rupiah Terhadap Return Saham Syariah Yang Terdaftar Di Bursa .... Jurnal Ilmiah UNTAG Semarang, 70-86. http://journal.undiknas.ac.id/index.php/akuntansi/article/view/22

Tandelilin, E. (2010). PORTOFOLIO dan INVESTASI Teori dan Aplikasi. Kanisius. 